\title{
The Effect of Different Dietary Practices on Workers and Queen Bee Formations in Honeybee (Apis mellifera L.) Larvae
}

\author{
Dilek KABAKCI ${ }^{1} *$ (D), Gökhan $\mathrm{AKDENIZ}^{2}$ (D) \\ ${ }^{1}$ Muş Alparslan University Faculty of Applied Sciences Departman of Animal Production and Technologies, \\ Muş, Turkey \\ ${ }^{2}$ Apiculture Research Institute, Ordu, Turkey
}

Geliş / Received: 24/04/2020, Kabul / Accepted: 25/12/2020

\begin{abstract}
Honey bee larvae feed on mandibular and hypopharyngeal gland secretions produced by Apis mellifera L. worker bees.In this study, 1-day-old larvae were transferred to Petri dishes and fed with diets in different sugar ratios. In the larvae fed daily, worker bee survival rate, weight, the number of adult individuals obtained and the probability of obtaining queen bees in individuals fed at different sugar ratios were determined. A $90 \%$ rate was achieved in workers who switched to the defecation phase in worker bees. In the queen bee group, a rate of $33 \%$ has made the transition to a defecation phase. It has been determined that there is a decrease in the life rate and weight of the larvae with the increase in the sugar content in the honey bee feeding and it is recommended not to feed with a high dose of sugar.
\end{abstract}

Keywords: Beekeeping, honey bee, feeding, in vitro, nurse bee

\section{Bal arısı (Apis mellifera L.) Larvalarında Farklı Diyet Uygulamalarının İşçi ve Ana Arı Oluşumu Üzerine Etkisi}

\section{Öz}

Bal arısı larvaları, Apis mellifera L. işçi arılar tarafından üretilen mandibular ve hipofaringal bez salgılarıyla beslenirler. Bu çalışmada 1 günlük yaştaki larvalar petri kaplarına transfer edilmiş ve farklı şeker oranlarında diyetlerle besleme yapılmıştır. Günlük olarak besleme yapılan larvalarda işçi arı yaşam oranı, ağırlığı, elde edilen yetişkin birey miktarı ve farklı şeker oranlarında besleme yapılan bireylerde ana arı elde etme olasılığ belirlenmiştir. İşçi arı bireylerinde defecasyon evresine geçiş yapanlarda \% 90 lık bir oran elde edilmiştir. Ana arı grubunda ise \% 33 bir oran defecasyon evresine geçiş sağlamıştır. Bal arısı beslemesinde şeker oranındaki artışla birlikte larvalarda yaşam oranı ve ağırlığında azalma olduğu belirlenmiş olup yüksek dozda şekerle besleme yapılmaması önerilmektedir.

Anahtar Kelimeler: Arıcılık, bal arısı, besleme, in vitro, işçi arı 


\section{Introduction}

The honey bee (Apis mellifera L.) is a very important source of pollinator for agriculture and human beings. Large losses occurring in the honey bee population recently pose a global pollination problem. Too much reduction in the number of pollinator insects (Gallai et al., 2009; Potts et al., 2010; Nieto et al., 2014) and the occurrence of large colony losses (Janke and Rosenkranz, 2009; Neumann and Carreck, 2010) have led to problems in many countries. Intensive pesticides used in the production of agricultural products also pose major problems for honey bees (Chan Mandy, 2012). It has also been determined by different researchers that honey bees are an important model organism for understanding the genomics, behavior genetics, development, and social behavior Chan Mandy,M.Y.(2012). Honey bees are social insects, and each colony is considered as a superorganism. Thus, within this social structure, which is defined as a colony, there are queen, worker, and drone bee individuals who are completely different from each other in terms of their development, lifetimes and duties. These individuals become mature by undergoing a complete metamorphosis starting from the egg stage. The nutritional needs, nutritional levels, energy and physiological needs of each of these individuals during egg, larval and adult age periods differ from each other significantly (Güler, 2017). Although the social structures of honey bees are attractive for studies, the brood feeding process carried out by worker bees manipulates our understanding of the difference in feeding and development of larvae, and honey bee-related research is far behind compared to other model organism research. Honey bee larvae are fed with nutrients produced from the hypopharyngeal and mandibular glands of worker bees. These nutrients differ in terms of the development of drones, worker bees, and queen bees (Johansson, 1955; Weaver, 1955; Rembold, 1965; Haydak, 1970; Dietz and Haydak, 1971; Brouwers, 1984; Howe et al., 1985; Kaftanoğlu et al., 2010; Güler, 2017). In vitro studies of honey bees are a method that has been used at the beginning to investigate differences of worker and queen bees, their nutrition, and pathogen effects (Rembold and Lackner, 1981; Vandenberg and Shimanuki, 1987). The balance of sugar, water, royal jelly and yeast in the diet of larvae was first determined by Rembold and Lackner (1981) in a laboratory setting. Later, Vandenberg and Shimanuki (1987) also developed the in vitro method by optimizing diet composition although a high percentage of worker bee individuals were obtained, any queen could not be bred. Peng (1992) also used this method to determine the toxicity, which is against the development of honey bees. Later, new breeding (beekeeping) methods have been also developed by different researchers (Hendriksma, Hartel, and Steffan-Dewenter, 2011b; Huang, 2009). The most important of these is the method which has been developed by Aupinel et al. (2005) and determines the main factors in the development of honey bees. All methods used in In Vitro breeding are based on the method of Vandenberg and Shimanuki (1987). However, other methods show differences in terms of the amount of diet given to the larvae and in terms of enough amount of diet added to the plastic queen cell cups daily. Kaftanoğlu et al. (2010) investigated viability and development in different sugar concentrations in order to perform beekeeping in vitro. In the research, 7 different sugar concentrations were studied (glucose), (fructose) $\quad(0 \% \mathrm{G}+0 \% \mathrm{~F}$, $3 \% \mathrm{G}+3 \% \mathrm{~F}, \quad 6 \% \mathrm{G}+6 \% \mathrm{~F}, \quad 12 \% \mathrm{G}+12 \% \quad \mathrm{~F}$, 
$0 \% \mathrm{G}+12 \% \mathrm{~F}, 12 \% \mathrm{G}+0 \% \mathrm{~F}$, and $4 \% \mathrm{G}+8 \% \mathrm{~F}$ ). In the study, individuals could not be raised on the 1st diet, but individuals were obtained from the 2 nd and 7 th diets. The aim of this study was to investigate the possibility of obtaining live individuals in the larvae transferred at the age of one day and the possibility of obtaining worker bees and queen bees by feeding the larvae with different diets.

\section{Material and Method}

This study was carried out in the apiary site and the Bee Health Laboratory of the Directorate of Ordu Apiculture Research Institute. Before this study, sterilization of all the instruments to be used was performed by keeping them at $121^{\circ} \mathrm{C}$ and under 1.5 atmospheric pressure for 15-20 minutes.

Equalization of Larval Age: Equalization of larval age was achieved through ensuring the queen bee to lay eggs by placing her in a two-frame cage in the colony and confining it for 24 hours. Previously prepared diets were weighed and taken into the Petri dishes. Then, the 1-day-old larvae were taken from frames and transferred to the Petri dishes.
Incubator Conditions: It is needed to create conditions in accordance with the criteria of $35{ }^{\circ} \mathrm{C}$ temperature and $86 \%$ humidity for the development of larvae and the criteria of 34 ${ }^{\circ} \mathrm{C}$ temperature and $70 \%$ humidity for the development of pupae. For these conditions, the Binder brand incubator, which was available in the Bee Health Laboratory, was used.

Desiccator: In order to set the appropriate temperature and humidity levels during the development process of the larvae, sulfuric acid obtained from a commercial company was used.

Table 1. The diet used for worker bee production

\begin{tabular}{lc}
\hline Royal jelly \% & 53 \\
Glucose $\%$ & 6 \\
Fructose $\%$ & 6 \\
Brewer's yeast \% & 1 \\
Distilled water \% & 34 \\
\hline Total & 100 \\
\hline
\end{tabular}

Table 2. Diets used for queen bee

\begin{tabular}{lcccc}
\hline Diets & $\mathbf{1}$ & $\mathbf{2}$ & $\mathbf{3}$ & $\mathbf{4}$ \\
\hline Royal jelly \% & 50 & 53 & 53 & 53 \\
Glucose \% & - & 12 & 15 & 18 \\
Fructose \% & - & 12 & 15 & 18 \\
Brewer's yeast \% & - & 1 & 1 & 1 \\
Distilled water \% & 50 & 22 & 16 & 10 \\
\hline Total & 100 & 100 & 100 & 100 \\
\hline $\begin{array}{l}\text { For worker bee production, 1-day old larvae } \\
\text { were transferred to diets, which were }\end{array}$ & $6 \%$ water and transferred to the Petri dish. After \\
prepared with 53\% royal jelly, 6\% glucose, & the transfer process, the larvae were fed daily
\end{tabular}


with 3.5-4.5 g diets for 6 days. For queen bee production, on the other hand, diets were prepared with different proportions of royal jelly, glucose, fructose, and distilled water, and 1-day old larvae were transferred. Prior to the defecation stage, the larvae were taken out from Petri dishes and weighed. They were then transferred to Petri dishes covered with tissue paper. The dirty tissue paper was removed the next day and the larvae were transferred to 24-well tissue culture plates to spend the pupation period.

Statistical Evaluation: In the interpretation of the study results, it was benefited from the descriptive statistics values, such as mean and percentage, for each property (parameter/variable) taken into account.

\section{Results}

During the Larval period, an average diet of 3.5-4.5 g was given to larvae and daily consumption was recorded. It was ensured that the larvae took the maximum diet that a larva could take daily. An average of $90 \%$ of the larvae, which were transferred to Petri dishes when they were 1-day old, survived and entered the post-defecation stage (Table $3)$. The weight of the larvae taken to the postdefecation stage was determined as $0.180 \mathrm{mg}$ on average.

Table 3. The survival rate of larvae during the larval period in worker bees

\begin{tabular}{lcccccccc}
\hline Individuals & $1^{\text {st }}$ day & $2^{\text {nd }}$ day & $3^{\text {rd }}$ day & $4^{\text {th }}$ day & $5^{\text {th }}$ day & $6^{\text {th }}$ day & $\begin{array}{c}\text { Survival } \\
\text { rate }(\%)\end{array}$ & $\begin{array}{c}\text { Warval } \\
\text { Weight }\end{array}$ \\
\hline $1^{\text {st }}$ group & 50 & 50 & 49 & 47 & 47 & 44 & 88 & 0.170 \\
$2^{\text {nd }}$ group & 50 & 48 & 47 & 47 & 47 & 45 & 90 & 0.190 \\
$3^{\text {rd }}$ group & 50 & 50 & 49 & 49 & 46 & 46 & 92 & 0.180 \\
\hline Total & 150 & 148 & 145 & 143 & 140 & 135 & 90 & 0.540 \\
\hline
\end{tabular}

Table 4. Adult bee amounts and output rates (\%)

\begin{tabular}{|c|c|c|c|c|c|}
\hline Groups & $N$ & $\begin{array}{c}\text { Amount of } \\
\text { living larvae } \\
\text { (number) }\end{array}$ & $\begin{array}{c}\text { Larval } \\
\text { survival rate } \\
(\%)\end{array}$ & $\begin{array}{l}\text { Amount of } \\
\text { adult bees } \\
\text { (number) }\end{array}$ & $\begin{array}{c}\text { Adult bee } \\
\text { output rate } \\
(\%)\end{array}$ \\
\hline $1^{\text {st }}$ group & 50 & 44 & 88 & 32 & $\% 72$ \\
\hline $2^{\text {nd }}$ group & 50 & 45 & 90 & 35 & $\% 77$ \\
\hline $3^{\text {rd }}$ group & 50 & 46 & 92 & 28 & $\% 60$ \\
\hline \multirow[t]{2}{*}{ Total } & 150 & 135 & $\% 90$ & 95 & $\% 69.6$ \\
\hline & & & \multicolumn{3}{|c|}{$\begin{array}{l}\text { While the larvae completed their } \\
\text { development at } 86 \% \text { humidity level at } 35{ }^{\circ} \mathrm{C} \\
\text { in the desiccator during the larval period, the } \\
\text { temperature within the desiccator was } \\
\text { reduced to } 35{ }^{\circ} \mathrm{C} \text { and the humidity to } 80 \%\end{array}$} \\
\hline
\end{tabular}


during the pupa period. In the study, $69.6 \%$ of the living larvae turned into mature bees at the end of the larval period in which feeding took place (Table 4).
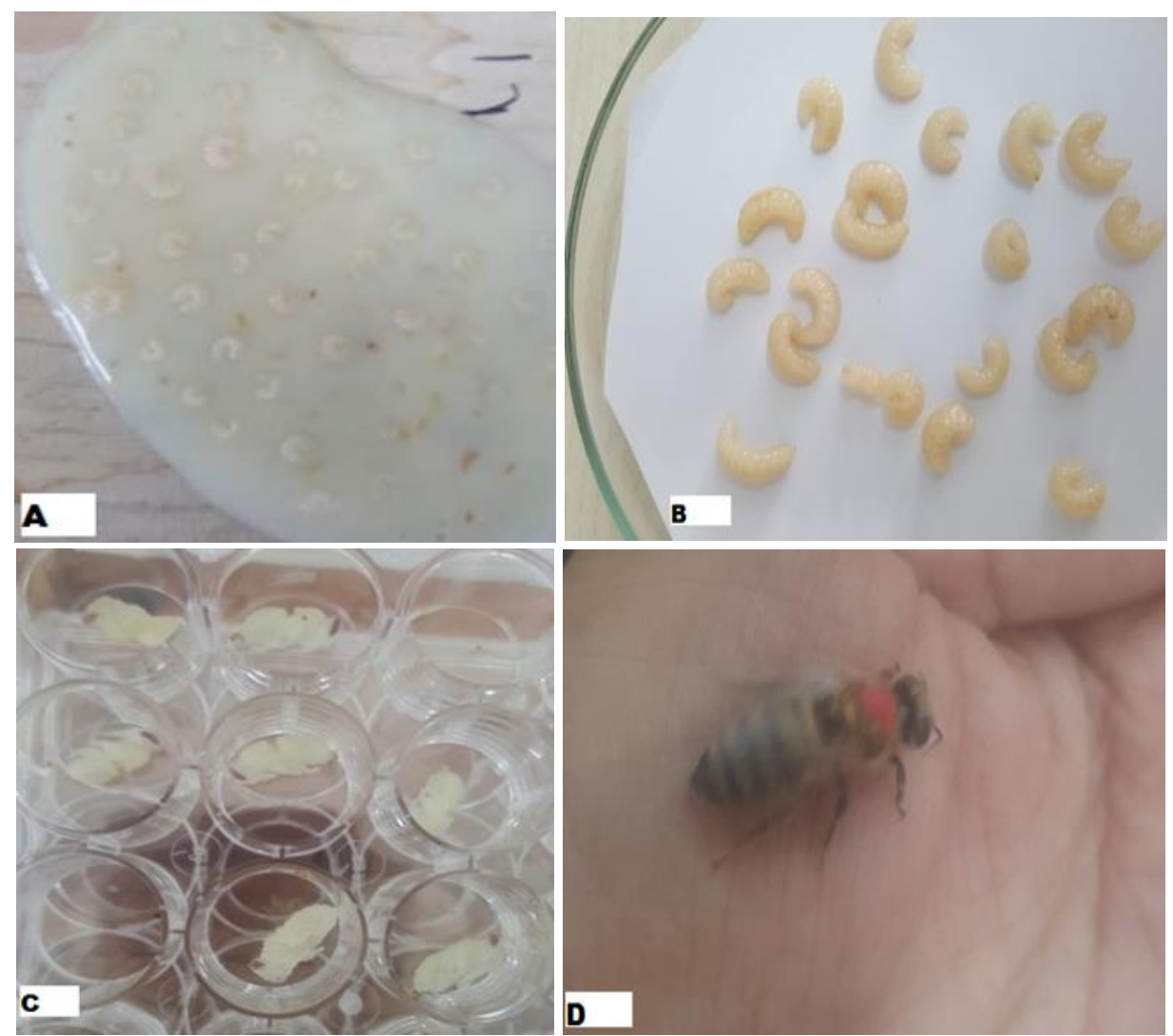

Figure 1: Rearing honey bee larvae in vitro A: grafting 1day old larvae into the aliquots of larval diets (Day 2), B: Larvae placed on filter paper; C: pupae in 24 well plates; D: adult bees reared in vitro.

The queen bee, worker bee, and drone diets differ from each other in terms of sugar content. The worker bee diet contains $12 \%$ sugar and the sugar source is glucose. Drone diets contain $34 \%$ sugar and the source of sugar is glucose. In the queen bee diets, on the other hand, the main source of sugar is glucose (Güler, 2017; Woodward, 2010). In line with the literature (Kaftanoğlu, 2011, Schmehl, 2016), sugar levels in different concentrations were used in in vitro queen bee breeding (Table 5).
In the study, in terms of the queen bee groups, although passing to the defecation stage was achieved in the group fed by royal jelly at 1:1 ratio at the end of the 3rd day, all the individuals in this group died by the end of the 4-5th day. Also in this group, it was observed that the sensitivity increased in the body tissues of the larvae. In addition, it was determined that the bees in other groups passed to the defecation phase at the end of the 6th day. The average larval weight in these groups was determined to be $0,85 \mathrm{mg}$. 
Table 5. Survival rates of the queen bee larvae

\begin{tabular}{lcccccccc}
\hline Groups & $\mathrm{N}$ & $1^{\text {st }}$ day & $2^{\text {st }}$ & $3^{\text {rd }}$ & $4^{\text {th }}$ & $5^{\text {th }}$ & $6^{\text {th }}$ day & $\begin{array}{c}\text { Larva } \\
\text { Weight }\end{array}$ \\
\hline 1 & 50 & 50 & 50 & 45 & - & - & - & - \\
2 & 50 & 50 & 48 & 48 & 41 & 40 & 35 & 0,168 \\
3 & 50 & 50 & 50 & 30 & 34 & 30 & 18 & 0,120 \\
4 & 50 & 50 & 50 & 39 & 37 & 33 & 13 & 0,52 \\
\hline Total & 200 & 200 & 198 & 162 & 112 & 103 & 66 & 0,340 \\
\hline
\end{tabular}

In the study, a decrease in the survival rates of larvae fed by diets with increased sugar concentration was seen. Our research results showed that in the group, which was fed with royal jelly and distilled water at a ratio of $1: 1$, all bees died at the end of the 4th day. In three diets with different sugar concentrations, \% 33 the larvae passed to the post-defecation stage at the end of the sixth day. Larvae fed with Diet 1, Diet 2 and Diet 3 died during the pupal period. On the other hand, all of the larvae in the group fed with Diet 4 died during the pupal period. The surviving $8 \%$ of the larvae, fed with diet 1 and diet 2, turned into the worker bee individuals.

\section{Discussion}

It has been reported by several researchers that the honey bee (Apis mellifera L.) is a very important model organism for understanding social behavior development and behavioral genetics (Page et al., 2006; Robinson et al., 2006). In this study, it was aimed to raise different honeybee individuals by using diets with different sugar ratios. In the literature, there are studies focusing on larval survival rate and average larval weight which take place among the results of our study. In their study conducted using different sugar concentrations, Kaftanoğlu et al. (2010) obtained 125 adult bees from a total of 180 larvae transferred. The study

reported that larvae had survival rates of 93.9\% and larval weight of $193.6 \mathrm{mg}$ during the post-defecation stage. In another study, Kaftanoglu et al. (2011) transferred a total of 350 1.5-2 day-old larvae into Petri dishes by using 7 different diets. In that study, 323 larvae entered the post-defecation phase and while the survival rates of these larvae were determined as $93.4 \%$, their average larval weight was determined as $208 \mathrm{mg}$. It has been observed that our research is consistent with these studies.

In their study with different pollen concentrations in vitro conditions, Veloso and Lourenço (2014) added pollen at rates of $2.5 \%, 5 \%$ and $10 \%$ to diets of larvae and transferred 3-day-old larvae to 96-well tissue culture plates. In the study, it was observed that 18 larvae survived in the control group, 9 larvae in the $2.5 \%$ pollen group, 6 larvae in the $5 \%$ pollen group, and 1 larva in the $10 \%$ pollen group. Larval weights were determined as 60.1, 74.8, 101.98, and 95.8. There are also several studies whose results are inconsistent with our study. For example, Chan Mandy, (2012) reported that 99\% of the individuals obtained by applying the general in vitro breeding protocol survive until the defecation stage, and adult individuals were obtained from $85 \%$ of those individuals. On the other hand, in their studies conducted with groups, which contained different sugar concentrations and 
were applied to raise queen bee, Kaptanoglu et al. $(2010,2011)$ reported that queen bee individuals could not be obtained and that the number of obtained individuals decreased as sugar concentration increased. Our research findings show similarities to these studies.

As a result, in the light of the findings we obtained from this study, in vitro conditions, it was determined that while the cultivation of honey bee individuals survived in individuals with different sugar concentrations, the rate of living in individuals decreased as the rate of sugar increased.

Acknowledgement: This article is based on the findings of research, which was finacially supported by TAGEM, with the proje number of TAGEM/HAYSUD/12/06/01/02.

\section{References}

Aupinel, P. Fortini, D. Dufour, H. Tasei, J.N. Michaud, B. Odoux, J.F. and Pham-Delegue, M. (2005). Improvement of Artificial Feeding in a Standard in vitro Method for Rearing Apis mellifera Larvae. Bulletin of Insectology, 58, 107-111.

Brouwers, E. V. M. (1984) Glucose / Fructose Ratio in the Food of Honey Bee Larvae During Caste Differentiation. Journal of Apicultural Research . 23(2): 94-101.

Chan Mandy M Y. (2012). A Thesis Submtted in Partial Fulfillment of the Requirements for the Degree of, (biochemistry and molecular biology) p:65.

Dietz, A. Haydak, M.H. (1971) Caste Determination in Honey Bees. I. The Significance of Moisture in Larval Food. Journal of Experimental Zoology . 177: 353358.
Gallai, N. Salles, J.M. Settele, J. Vaissière, B.E. (2009). Economic Valuation of the vulnerability of world Agriculture Confronted with Pollinator Decline. Ecol. Econ. 68, 810-821.

Güler, A. (2017)., Besin Madde İhtiyaçları ve Beslenme, Bal Arıs1 (Apis mellifera L) Yetiştiriciliği Hastalıkları ve Ürünleri. 1. Bask1. Azim Matbaacılık. S. 120 - 121.

Haydak, M. H. (1970) Honey Bee Nutrition. Annual Review of Entomology . 15: 143156.Hendriksma, H.P. Hartel, S. And Steffan-Dewenter, I. (2011b). Honey Bee Risk Assessment: New Approaches for in Vitro Larvae Rearing and Data Analyses. Methods in Ecology and Evolution, 2, 509517. doi:10.1111/j.2041210X.2011.00099.x.

Hendriksma, HP. Härtel, S. SteffanDewenter, I. (2011) Honey bee risk assessment: new approaches for in vitro larvae rearing and data analyses. Methods Ecol. Evol., 2, 509-517

Howe, S. R. Dimick, P.S. Benton, A.W. (1985) Composition of Freshly Harvested and Commercial Royal Jelly. Journal of Apicultural Research . 24(1): 52-61.

Huang, Z. (2009). A Standardized Procedure for the in Vitro Rearing of Honey Bee Larvae. Retrieved from www.cdpr.ca.gov/ docs/registration/reevaluation/larval_protocol .pdf.

Janke, M. Rosenkranz, P. (2009) Periodical Honey Bee Colony Losses in Germany: Preliminary Results from a Four Years Monitoring Project. Julius-Kühn-Archiv 423, 108-117.

Johansson, T.S. K. (1955) Royal jelly. Bee World. 36: 1-13, 21-32. 
Kaftanoğlu, O. Linksvayer, A. T. Page, R. 2010. Rearing Honey Bees ( Apis mellifera L.) In Vitro Effects of Feeding İntervals on Survival and Development. Journal of Apicultural Research and Bee World 49(4): 311-317.

Kaftanoğlu, O. Linksvayer, A. T. Page, R. 2011. Rearing Honey Bees, Apis mellifera, in vitro 1: Effects of Sugar Concentrations on Survival and Development, Journal of Insect Science: Vol. 11.

Neumann, P. Carreck, N.L. (2010) Honey Bee Colony Losses. J. Apic. Res. 49, 1-6.

Nietto, A. Roberts, S.P.M. Kemp, J. Rasmont, P. Kulman, M. 2014 EuropeanRedListofbees. Publication Office of the European Union, Luxembourg.

Page, R E. Scheiner, R. Erber, J. Amdam, G.V. (2006) The Development and Evolution of Division of Labour and Foraging Specialization in a social İnsect ( Apis mellifera L.). Current Topics in Developmental Biology 74: 253-286. DOI: 10.1016/S0070-2153 (06)74008-X.

Potts, S.G. Biesmeijer, J.C. Kremen, C. Neumann, P. Schweiger, O. Kunin, W.E. (2010) Global Pollinator Declines: Trends, İmpacts and Drivers. Trends Ecol. Evol. 25, 345-353.

Peng, Y S C. Mussen, E. Fong, A. Montague, M A. Tyler, T. (1992) Effects of chlortetracycline on honey bee worker larvae reared in vitro. Journal of Invertebrate Pathology. 60: 127-133.

Rembold, H. (1965). Biologically Active Substances in Royal Jelly. Vitamins and Hormones . 23: 359-382.
Rembold, H. Lackaner, B (1981) Rearing of honey bee larvae in vitro: Effect of yeast extract on queen differentiation. Journal of Apicultural Research. 20(3): 165-171.

Robinson, G. E. Evans, J. D. Maleszka, R. Robertson, H.M. Weaver, D.B; Worley, Y. K. Gibbs, R. A. Weinstock, G.M. (2006) Sweetness and Light: Illuminating the Honey Bee Genome. Insect Molecular Biology . 15(5): 535-539. DOI: 10.1111/j.136522583. 2006.00698.x.

Vandenberg, J. D. and Shimanuki, H. (1987). Technique for Rearing Worker Honey Bees in the Laboratory. Journal of Apicultural Research, 26, 90-97. doi: 10.1080/00218839.1987.11100743.

Veloso, A.J Lourenço A.P. (2014). Pollen Diet For In Vitro Rearıng Of Africanızed Honey Bee Larvae, Apis mellifera (Hymenoptera: Apidae). Biosci. J., Uberlândia, v. 30, n. 1, p. 288-296.

Weavern, N. (1955) Rearing of Honey Bee Larvae on Royal Jelly in the laboratory. Bee World 36(9): 157-159.

Woodward, D.R. (2010) Queen bee Biology, Rearing and Breeding. Nothern Bee, p: 5. 